Volume and Issues Obtainable at Center for Sustainability Research and Consultancy
Sustainable Business and Society in Emerging Economies
ISSN: $2708-2172$ \& (E): 2708-2504
Volume 3: Issue 4 December 2021

\title{
Ensuring Viable Solutions in Resource-Constrained Language Teaching Settings: ESL Learners Perceptions about Computer Assisted Language Testing (CALT)
}

\author{
*Riaz Hussain, Department of English Linguistics, the Islamia University of Bahawalpur, Pakistan \\ Muhammad Sumair Zahid, Department of English Linguistics, the Islamia University of Bahawalpur, \\ Pakistan \\ Youshaib Alam, Department of English, Khawaja Fareed Graduate College, Rahim Yar Khan, Pakistan \\ *Corresponding author's email address: dr.riazhussain@iub.edu.pk
}

\begin{tabular}{l}
\hline ARTICLE DETAILS \\
\hline History \\
Revised format: Nov 2021 \\
Available Online: Dec 2021 \\
\hline Keywords \\
Computer-Assisted Language \\
Testing (CALT), Language \\
proficiency test, Testing \& \\
Evaluation, in Teaching \\
English Resource- \\
constrained setting \\
\hline
\end{tabular}

JEL Classification

A20, A29

\begin{abstract}
Purpose: Across the globe, organizations operating in testing services have made optimum use of this technology and seem to have won greater trust and confidence of the test-takers. The purpose of the current study was to explore the perceptions of ESL learners about Computer-Assisted Language Testing (CALT). It further aimed to investigate the challenges and problems learners encounter during the test.

Design/Methodology/Approach: The current study had two phases: CALT test and a questionnaire-based survey. In the first phase, the researchers designed and conducted a CALT test to give learners some exposure of CALT. With a quantitative approach, the researchers in the current study designed, piloted and administered a close-ended questionnaire to collect data about learners' perceptions about CALT.

Findings: The results revealed that the learners had positive perceptions about CALT. Some learners encountered challenges while practicing in CALT. Around $80 \%$ of the learners thought CALT was adequate in assessing the English language proficiency of the learners and that it was compatible with the existing circumstances.

Implications/Originality/Value: In Pakistan, insufficient number of studies seemed to have been done by the researcher. The current study fills the existing gap.
\end{abstract}

(C) 2021 The authors, under a Creative Commons AttributionNonCommercial- 4.0

\footnotetext{
Recommended citation: Hussain, R., Zahid, M. S. \& Alam, Y. (2021). Ensuring Viable Solutions in ResourceConstrained Language Teaching Settings: ESL Learners Perceptions about Computer Assisted Language Testing (CALT). Sustainable Business and Society in Emerging Economies, 3 (4), 509-519.
}

\section{Introduction}

Universities exist as solution providers in society. Research and innovations require investment and funding. Therefore, for centuries prosperous governments and wealthy patrons have been patronizing education, research, innovations, creativity, and inventions in different parts of the world. The House of Wisdom established by the Abbasids in the Middle East stands out in the scrolls of history as a glorious example of governments patronizing intellectual advancements (Heide, \& Gilliland, 1999 and Al- 
Khalili, 2011). In Pakistan, in the princely state of Bahawalpur, the Nawab of Bahawalpur, Nawab Sadiq Muhammad Khan V, was famous for his patronage of scholarly works and educational institutes. The time-honored Jamia Abbasia which is these days known as the Islamia University of Bahwalpur was envisioned and established by the worthy Nawab (Mohsin and Hameed, July 15, 2013). In the $21^{\text {st }}$ century, Pakistan is trying to achieve prosperity and get rid of reliance on foreign aid. The government is trying to pay off foreign loans and is resorting to austerity measures. These austerity measures and budget cuts seem to have affected some sectors funded by the government. Higher Education in Pakistan seems to experience financial crisis these days. Bothwel (July 01, 2019), Abbasi (January 30, 2020) and Ashfaq (April 11, 2021) report about funding problems for the public universities of Pakistan. They argue that some government universities during the last five years are struggling to meet salary and other expenditures due to the denial of funds by higher authorities. Furthermore, the pandemic COVID-19 has also affected education globally. A number of private schools and colleges ended their set-ups in the wake of the pandemic in Pakistan due to financial problems and lack of sufficient income. But, limitations and constraints should not prevent teachers from ensuring quality language teaching. English Language Teaching (ELT) has been carried out by teachers in resource-constrained settings. West (1966) gave detailed discussions on teaching English in difficult circumstances highlighting no-cost or low-cost resources teachers could utilize and exploit from the existing environment. In addition to lack of funds, another limitation is size of the classes. In a country like Pakistan, in state-run institutes, large classes are expected. Shamim and Kuchah(2016) have talked about this problem with reference to countries with large populations. Sulistyowati (2012) talked about turning large classes into small classes with motivation and attention. Thus, linguists and educationists have talked about solutions in problematic situations. In the current crisis, educational administrators, educationists and language teachers are trying to adopt their practices to the changing circumstances.

The 21 st century is the age of information technology and data. Information technology seems to have revolutionized language learning, language teaching, and language testing. The use of information technology in language testing has expedited the process of evaluation. These and other features of computer-based language testing seem to attract educationists and linguists. Computer-Assisted Language Testing (CALT) was an emerging domain of applied linguistics till 2019. After the breakdown of the COVID-19 pandemic, educationists and test-takers were left with no other choice but to embrace the online modes of teaching, learning and assessment. Computer-Assisted Language Learning (CALL) and Computer-Assisted Language Testing (CALT) were in use in English Language Teaching (ELT) settings in Pakistan and all over the globe. The outbreak of the pandemic and the consequent financial and social problems increased their importance. A good number of studies have been done on CALL in Pakistan and around the globe. The studies done by Warschauer (1996), Warschauer (1997), Levy (1997), Levy (2009), Amjid, Hussain \& Siddiq (2020), and Asgher and Hanif (2021) are a few examples in this case. But, the field CALT seems to get less attention of the researchers of linguistics. However, in the background of the pandemic and the financial crunch, CALT seems to have gained greater importance as an economical and viable solution in the post-COVID-19 era.

\section{Research Question}

1. What are ESL learners' perceptions about Computer-Assisted Language Testing?

2. What challenges and problems could the learners face while attempting computer-assisted language test?

3. Is CALT helpful for ESL learners in measuring their English language proficiency?

\section{Statement of the Problem}

The present study centers on the development of a Computer-assisted language test for testing English language proficiency of the ESL learners. It further investigates ESL learners' perceptions about CALT and focuses on the problems that learners face while attempting a self-designed computer-assisted language test. 


\section{Literature Review}

The available literature on the subject focuses on CALL and CALT. Some of the insights and aspects from the relevant literature have already been discussed in the introduction of the study. The following paragraphs contain discussions from the literature on CALT and its relevant framework, principles and factors for designing CALT.

\section{What Is Computer-Assisted Language Testing (CALT)}

Computer-Assisted Language Testing (CALT) employs computer applications or online databases for evaluating ESL or EFL learners' performance in a second or foreign language (Suvorov and Hegelheimer, 2013). According to Pathan (2012), computer-assisted language assessment or Computer-Assisted Language Testing (CALT) is referred to the implementation of computer technology in language testing. Altogether, CALT implicates a language test using computer technology for the assessment of language learners. Chapelle and Douglas (2006) highlight three motives for using technology in language testing which include efficiency, equivalence, and innovation. Noijons (2013) also discusses the similar criteria for employing computer technology in language testing, includes formation of the test, interaction of computer with test-taker, and evaluation of test taker's responses.

\section{Framework for the Description of Calt}

Suvorov and Hegelheimer (2013) have set a framework comprising of nine attributes for the description of CALT. The first five aspects are particularly associated with CALT.

Table 1: Framework for CALT based on Suvorov and Hegelheimer (2013)

\begin{tabular}{ll}
\hline Attributes & Categories \\
\hline Directionality & Linear, adaptive, and semi-adaptive testing \\
\hline Delivery format & Computer-based and Web-based testing \\
\hline Media density & Single medium and multimedia \\
\hline Target skill & Single language skill and integrated skills \\
\hline Scoring mechanism & Human-based, exact answer matching, and analysis-based scoring \\
\hline Stakes & Low stakes, medium stakes, and high stakes \\
\hline Purpose & Curriculum-related (achievement, admission, diagnosis, placement, \\
& progress) and non-curriculum-related (proficiency and screening) \\
\hline Response type & Selected response and constructed response \\
\hline Task type & Selective (e.g., multiple choice), productive (e.g., short answer, \\
cloze task, written and oral narratives), and interactive (e.g., \\
matching, drag and drop)
\end{tabular}

\section{Development of Calt}

CALT supports the principles of practicality, validity and reliability like other language tests. Noijons (2013) infers about validity as a principle that evaluates if a test fulfills the purpose of assessment. Reliability is defined as how much a construct shows consistency, and produces reproducible scores (Noijons, 2013). The complications that CALT may face related to validity and reliability, are mentioned in the given literature.

\section{Validity of Calt Test}

Considering validity in the development of CALT may result in some issues, but there is no reason for CALT that it should construct less valid test as compared to the conventional tests. In many cases, it is experienced that test designers or developers plan for a test with various targets to achieve but the constructs do not follow the planned objectives due to the limitations of designer, system, and language (Green, 1988). Moreover, CALT cannot be considered as a valid method for testing language proficiency or skill as Noijons (2013) argues that CALT is not a valid test all the time, for instance, while evaluating reading comprehension items, memory and optical stamina can influence the results of reading comprehension exercises. Moreover, the main concern about validity is, there 
should be a valid procedure of items selection. So that, each task and item in the test may evaluate proficiency at the same level.

\section{Reliability of Calt Test}

Noijons (2013) defines reliability as the degree to which the scores of a test are reproducible and consistent. Computer-assisted language tests are more reliable as compared to the conventional tests. It is the point at which CALT may have an advantage over conventional methods of testing as marked answers on answer sheet are difficult for a machine to read with $100 \%$ accuracy, and processing of the answers by human evaluators may result in errors. In such a case, CALT is more accurate and controlled.

Noijons (2013) raises four questions considering reliability.

- If each test can be reproduced and can provide a record of the assignment, given to the testee?

- Will the score of testee remain the same if tested under similar circumstances again?

- If a test is foolproof and guarantees for uninterrupted testing?

- Is there any intermediating factor involved (i.e. change in background noise, lighting, and localities)?

\section{Test Factors}

Before developing or employing any existing application for designing computer-assisted language tests, it is ideal for a test taker to have a systematic review considering important factors of language testing. Alessi and Trollip (1985) devised a checklist of key factors for testing. Test factors are divided into three stages (before, during, and after) based on the content and administration of the test (See Table 2).

Table 2: Table of Factors on CALT Alessi and Trollip (1985).

\begin{tabular}{c|l|l|} 
Test Content & \multicolumn{2}{c}{ Taking the Test } \\
\hline Function/ Purpose & Entrance to the Test & \\
\hline Test Objective & Test instructions & \\
\hline Test Length & Examples of items & \\
\hline Generating Items & Checking of Test & \\
\hline Item type & Fraud & \\
\hline Feedback & Feedback \\
\hline Time & Breakdowns \\
\hline Responses Registration & End of Test & \\
\hline Evaluation & Storage of Data \\
\hline
\end{tabular}

\section{Test Factors}

Technical advancement in the field of language assessment has given birth to the domain of Computer-Assisted Language Testing (CALT) which particularly aims at restructuring the nature of language assessment (Pathan, 2012). Researchers came across profound studies while exploring the role of computers in the process of language teaching and testing. Dandonoli (1989), Larson (1989), Madsen (1986, 1991), Neu and Scarcella (1991), Brown (1997), Carol A. Chapelle and Dan Douglas 
(2006), Pathan (2012), Larson and Madsen (2013), and Milliner and Barr (2017). supported the use of computers in language testing due to advantageous outcomes in language testing and assessment. Moreover, researchers put efforts to sort out the process of developing computer-assisted language tests. Particularly, Brown (1997) had assessed various developments of the time i.e. the use of item bank, new technologies, CAT, and impact of computers in language testing, and provided future directions for the development of CALT. Suvorov and Hegelheimer (2013) presented a brief introduction of the discipline and a framework for the description of computer-assisted language tests. Nojoins (2013) worked on the principles of language testing i.e. validity and reliability and developed a checklist of the factors affecting CALT. Milliner and Barr (2017) introduced the procedure of CALT development for the internet-connected English classrooms and provided an efficient and effective way for teachers to manage assessments, homework, and classroom-related tasks online. Chapelle and Douglas (2006) identified three major advances in language assessment through CALT and identified the impacts of CALT in Applied Linguistics. Chapelle and Douglas (2006) elaborated the significant role of computer technology in language testing and presented a volume comprised of six chapters which comprised of studies on the development of CALT, the roles of instructors and test developers in getting familiar with the new language testing technologies, comparison of conventional testing with technology-based testing and assessments, validity issues of computer-assisted language test, online software for the implementation of CALT, evaluation of CALT and the impacts of CALT. For using technology in language testing, three main motives were distinguished by Chapelle (2010). These motives of using the technology in language testing are efficiency, equivalence, and innovation which deal with the concepts like automated evaluation process of writing and speech, the equivalency of computerized tests to conventional paper-based tests, and transformation of language testing. Sulaiman and Khan (2019) discussed challenges and issues of Computer-Assisted Language Testing.

At present, the vitality of CALT has been acknowledged by various researchers and testers. This discipline is emerging in the global world as CALL is making progress. CALL employs computer applications aimed at developing skills or proficiency of language and CALT is meant to be a measuring instrument or technique (Nojoins, 2014). While discussing the future of CALL and CALT, Indrawati (2008) has advocated that Computer and technology would continue to flourish, so there is no need to be doubtful about the use of both in language teaching and testing. Although computers cannot replace language teachers, test takers, and raters, it can be employed to help test takers and instructors to facilitate the best teaching and test-taking skills.

\section{Research Methodology}

Research methodology of a study refers to processes, tools, methods and techniques used adopted or followed to collect data, and analyze it. A description of research methodology is necessary because it gives details about the transparency, validity and reliability of a research study. The current study had two phases: CALT test and a questionnaire-based survey. In the first phase, the researchers designed and conducted a CALT test to give learners some exposure of CALT. With a quantitative approach, the researchers in the current study designed, piloted and administered a close-ended questionnaire to collect data about learners' perceptions about CALT. The following image 1 shows the test conducted for the current study. 


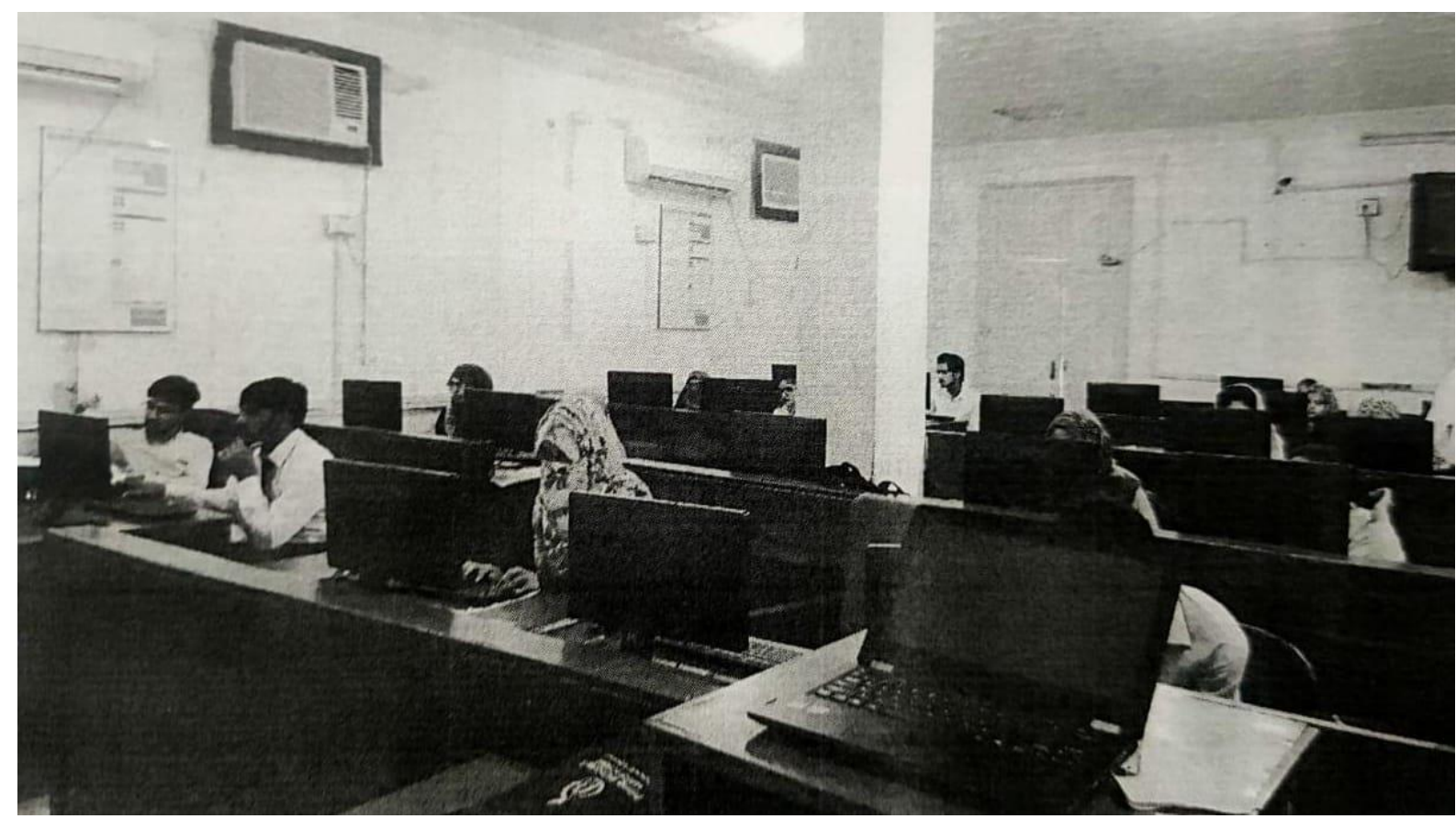

Image 1: ESL Learners taking CALT Test Designed by the researchers

\section{Research Design}

Research Design is a plan that is employed to investigate the answers of particular research questions. Moreover, it outlines the process of sample selection, data collection, and data analysis. The proposed study used quantitative approach and it is descriptive in nature. The descriptive study involves surveys, questionnaires, and interviews as a tool of data collection. According to Borg and Gall (1989), it studies perspectives, attitudes, opinions, behaviors of a population and answers to the question "What". In the research study, a close-ended questionnaire was employed to collect quantitative data. O' Malley and Chamot (1990) indicate that for the collection of data from a large number of population and, handing over questionnaires to the participants is quite practical and easier than conducting an interview. It allows maximum participation maintaining the secrecy of the respondents.

\section{Research Setting}

The current study was conducted at the department of English, The Islamia University of Bahawalpur. The Islamia University of Bahawalpur is one of the time-honored universities of Pakistan.

\section{Research Tool}

The research study explored ESL learners' perceptions about Computer-Assisted Language Testing. For this purpose, a questionnaire was developed by the researchers for data collection. According to Gault (1907), a questionnaire is comprised of a set of statements used for collecting statistical and numerical data. The target population for data collection consisted of one hundred ESL learners of the Islamia University of Bahawalpur. It is significant in research to evaluate information under study accurately as a research tool should be valid and reliable. For the authenticity of the research study, a pilot study was conducted on a similar sample. Later, the collected data was used to pilot the research study. Errors and omissions were removed and after achieving the standard reliability and validity, the close-ended questionnaire was ready for the study. The reliability was tested by applying Cronbach's Alpha using Statistical Package for Social Sciences (SPSS) 22. The reliability score was $0.852(85 \%)$ that depicted the reliability status of the research tool. Using the technique of Simple Random Sampling (SRS), 100 regular students of the English department enrolled at IUB were chosen for the data collection. According to Thomas (2020), it is a randomly selected subgroup of a population in which each participant of the population has an exactly equal probability of being selected. Since, BS students were known best for their English language proficiency and systematic study of English language, they 
proved a better sample for the required study. After attempting the computer-assisted language test designed by the researchers, participants submitted their responses. Responses were presented in the form of 5 points Likert scale of agreement. It is an effective and useful way to determine attitudes and opinions of respondents (Turner, 1993).

\section{Data Analysis \& Findings}

As discussed, a close-ended questionnaire was used to collect the data following five points Likert scale. The collected data were analyzed by using SPSS 22 to calculate frequency and percentage. After analyzing the quantitative data, the data were presented into tabulated form that further contributed in the findings of the research study.

Figure 1: ESL learners' perceptions about Computer-Assisted Language Testing (CALT)

\section{Statements}

\section{Strongly Agree Neither Agree Nor Strongly Disagree Agree Disagree}

\begin{tabular}{|c|c|c|c|c|c|}
\hline $\begin{array}{l}\text { A little knowledge of computer and online testing is } \\
\text { enough to attempt this test online }\end{array}$ & $47 \%$ & $39 \%$ & $7 \%$ & $2 \%$ & $5 \%$ \\
\hline CALT is easy in its use & $40 \%$ & $44 \%$ & $12 \%$ & $1 \%$ & $3 \%$ \\
\hline CALT is an interesting technique for classroom testing & $53 \%$ & $29 \%$ & $3 \%$ & $4 \%$ & $11 \%$ \\
\hline CALT follows modern trends of language testing & $46 \%$ & $43 \%$ & $5 \%$ & $2 \%$ & $4 \%$ \\
\hline Quick results can help me to work on my weaknesses. & $57 \%$ & $35 \%$ & $6 \%$ & $1 \%$ & $1 \%$ \\
\hline It will improve my performance for the next test. & $53 \%$ & $43 \%$ & $3 \%$ & $1 \%$ & \\
\hline $\begin{array}{l}\text { CALT is helpful in assessing ESL learners' reading } \\
\text { proficiency }\end{array}$ & $32 \%$ & $54 \%$ & $7 \%$ & $2 \%$ & $5 \%$ \\
\hline $\begin{array}{l}\text { CALT assists in measuring ESL learners' listening skills } \\
\text { which conventional test fails to do }\end{array}$ & $38 \%$ & $49 \%$ & $10 \%$ & $2 \%$ & $1 \%$ \\
\hline Immediate feedback of CALT saves the time of testees. & 54 & 37 & 7 & 1 & 1 \\
\hline $\begin{array}{l}\text { Immediate feedback can help ESL learners in the } \\
\text { correction of vocabulary mistakes }\end{array}$ & $40 \%$ & $46 \%$ & $3 \%$ & $7 \%$ & $4 \%$ \\
\hline $\begin{array}{l}\text { Immediate feedback can help ESL learners in the } \\
\text { correction of grammatical mistakes }\end{array}$ & $44 \%$ & $39 \%$ & $7 \%$ & $4 \%$ & $6 \%$ \\
\hline $\begin{array}{l}\text { CALT can be helpful for English language learners as a } \\
\text { tool of self-assessment }\end{array}$ & $48 \%$ & $31 \%$ & $9 \%$ & $3 \%$ & $9 \%$ \\
\hline $\begin{array}{l}\text { Quick and automated scoring can help learners to work } \\
\text { on their weaknesses }\end{array}$ & $57 \%$ & $35 \%$ & $6 \%$ & $1 \%$ & $1 \%$ \\
\hline $\begin{array}{l}\text { Computer-Assisted Language Testing is better as as } \\
\text { compared to the conventional paper-based tests }\end{array}$ & $33 \%$ & $47 \%$ & $15 \%$ & $4 \%$ & $1 \%$ \\
\hline $\begin{array}{l}\text { CALT helps learners by reducing learners' anxiety } \\
\text { during the test }\end{array}$ & $46 \%$ & $43 \%$ & $8 \%$ & $1 \%$ & $2 \%$ \\
\hline $\begin{array}{l}\text { I have been provided with the required technical } \\
\text { information before the test }\end{array}$ & $18 \%$ & $51 \%$ & $14 \%$ & $6 \%$ & $10 \%$ \\
\hline $\begin{array}{l}\text { Computer-Assisted Language Testing is a valuable } \\
\text { extension of classical testing techniques }\end{array}$ & $27 \%$ & $50 \%$ & $18 \%$ & $4 \%$ & $1 \%$ \\
\hline $\begin{array}{l}\text { It can improve English language learners' academic } \\
\text { achievement. }\end{array}$ & $44 \%$ & $43 \%$ & $3 \%$ & $4 \%$ & $6 \%$ \\
\hline
\end{tabular}

English language learners had positive perceptions about Computer-Assisted Language Testing. Different aspects of learners' perceptions were evaluated, including their perceptions about ComputerAssisted Language Testing and its use and usefulness as a language test. Results depicted that $88 \%$ of the respondents found CALT easy in use and $67 \%$ of them considered it a useful assessment tool. There were questions related to computer literacy and the findings showed that $86 \%$ of English language learners were competent and proficient in computer use while $75 \%$ of them were experiencing computer-assisted language test first time. Albeit, a majority of $82 \%$ respondents found CALT as an interesting technique for classroom and examination testing. Moreover, $87 \%$ thought that CALT could be helpful in improving the academic achievement of language learners. A majority of respondents 
believed that it could be helpful in evaluating their listening (87\%) and reading (86\%) proficiency. $77 \%$ of the research participants found it better and unique as compared to the conventional Paper-pencil testing and $79 \%$ agreed that CALT could be used as a self-assessment tool. $54 \%$ of the respondents strongly while $37 \%$ of the respondents agreed that unique features of CALT like automated scoring $(92 \%)$ and immediate feedback $(83 \%)$ made it useful for both learners and teachers. A majority of $89 \%$ also believed that it could be helpful in reducing learners' anxiety and could play the role of a friendly test. $77 \%$ of the participants supported the idea that proper training of teachers and learners was needed for practicing CALT. About $69 \%$ of English language learners declared that they had been provided with the proper training and required technical and informative support during test. The availability of support could affect language learners' performance as it may minimize the learners' mistakes (Bueno and Salmeron, 2008). In the end, $77 \%$ of the respondents agreed that CALT was a valuable extension of classical testing techniques and $75 \%$ believed that CALT was as valuable as conventional testing was.

Figure 2: Challenges and problems while undertaking computer-assisted language test

$\begin{array}{lllll}\text { Statements } & \begin{array}{l}\text { Strongly } \\ \text { Agree }\end{array} & \text { Agree } & \begin{array}{l}\text { Neither } \\ \text { Agree Nor Disagree } \\ \text { Disagree }\end{array} & \text { Disagree }\end{array}$

\begin{tabular}{|c|c|c|c|c|c|}
\hline $\begin{array}{l}\text { Internet connectivity gets slow at times, it } \\
\text { hampered my progress }\end{array}$ & $21 \%$ & $36 \%$ & $20 \%$ & $10 \%$ & $13 \%$ \\
\hline $\begin{array}{l}\text { For Computer-assisted language tests, } \\
\text { Learners should be provided with } \\
\text { information and proper training }\end{array}$ & $21 \%$ & $56 \%$ & $16 \%$ & $3 \%$ & $4 \%$ \\
\hline $\begin{array}{l}\text { It is difficult to do the reading } \\
\text { comprehension questions on the computer } \\
\text { screen }\end{array}$ & $7 \%$ & $33 \%$ & $21 \%$ & $12 \%$ & $27 \%$ \\
\hline $\begin{array}{l}\text { The long-term computer use in a test is } \\
\text { hectic }\end{array}$ & $19 \%$ & $37 \%$ & $27 \%$ & $8 \%$ & $9 \%$ \\
\hline $\begin{array}{l}\text { I do not have knowledge about computer so } \\
\text { it is a useless technique for me }\end{array}$ & $8 \%$ & $12 \%$ & $13 \%$ & $40 \%$ & $27 \%$ \\
\hline
\end{tabular}

The findings of the study indicated that some students encountered challenges while practicing CALT. Even the English language learners, who were proficient in computer use, experienced the same challenges. One of the challenges was of Internet connectivity. 57\% of the learners declared that internet connectivity got slow at times and it affected the progress of English language learners. The possible solution was that the institution should provide fast and reliable internet connection (Mukandutiye, Sevilla and Makhanu, 2014). A few students had faced another issue related to computer competency as they don't know how to operate a computer so $20 \%$ of them found it useless technique. So, possible solution could be the training of the English language learners before the test. Even, it was difficult for $40 \%$ of ESL learners to do reading comprehension questions on screen as long term use of computer could be hectic and might affect the cognitive ability of language learners while reading long texts. The possible solution suggested by Kurniawan and Zaphiris (2001) that online reading could be slower than on paper so a test developer should use big fonts, high contrast between text and background to enhance online reading speed of the learner. Another solution could be the use of low brightness devices (Nikou and Economides, 2013).

Figure 3: CALT as an English language proficiency test 


\begin{tabular}{|c|c|c|c|c|c|}
\hline Statements & $\begin{array}{l}\text { Strongly } \\
\text { Agree }\end{array}$ & Agree & $\begin{array}{l}\text { Neither } \\
\text { Agree } \\
\text { Nor } \\
\text { Disagree }\end{array}$ & $\begin{array}{l}\text { Strongly } \\
\text { Disagree }\end{array}$ & Disagree \\
\hline $\begin{array}{l}\text { Computer-assisted language test is } \\
\text { adequate in assessing English language } \\
\text { proficiency of learners in Pakistan. }\end{array}$ & $39 \%$ & $43 \%$ & $10 \%$ & $5 \%$ & $3 \%$ \\
\hline $\begin{array}{l}\text { CALT may prove helpful in maintaining the } \\
\text { same standard of English language testing } \\
\text { in Pakistan, which International language } \\
\text { testing has. }\end{array}$ & $40 \%$ & $40 \%$ & $16 \%$ & $2 \%$ & $2 \%$ \\
\hline $\begin{array}{r}\text { I suggest CALT should be practiced in all } \\
\text { the universities of Pakistan. }\end{array}$ & $55 \%$ & $34 \%$ & $5 \%$ & $1 \%$ & $5 \%$ \\
\hline $\begin{array}{l}\text { There is need of development in English } \\
\text { language testing. I think CALT is a } \\
\text { requirement of time. }\end{array}$ & $41 \%$ & $46 \%$ & $7 \%$ & $4 \%$ & $2 \%$ \\
\hline
\end{tabular}

Around, $82 \%$ of the learners thought CALT was adequate in assessing the English language proficiency of the learners and $80 \%$ believed that it would be helpful in maintaining the same standard of English language testing in Pakistan which international language testing has and $86.8 \%$ of the respondents considered it as a requirement of time.

\section{Conclusion}

The findings from the questionnaire indicated that English language learners' perceptions about computer-assisted language test were adequately positive. Even after experiencing a few challenges, learners perceived that CALT was convenient in measuring their English language proficiency. Learners showed the complete willingness for accepting CALT a tool of assessment and suggested this type of test for the other universities of Pakistan as well. Furthermore, the participants of the study were the English language learners who had a complete access to computers and E-Labs of the University and some people may call it a fact that technology always impacts learners in a significant way. Therefore, CALT can be an inspiration for the learners and may provide them great assistance in the teachinglearning process. The findings of this research may provide directions to the language teachers and course instructors to make computer-assisted language test a part of their language teaching practice as a majority of language learners depicted a positive attitude towards CALT.

\section{References}

Abbasi.K(January 30, 2020). Public universities undergoing financial crisis. The Nation. Retrieved on January 1, 2021, from https://nation.com.pk/30-Jan-2020/public-universities-under-goingfinancial-crisis

Alessi, S. M., \& Trollip, S. R. (1985). Computer-based instruction: Methods and development. Englewood Cliffs, N.J: Prentice-Hall.

Al-Khalili, J. (2011). The house of wisdom: How Arabic science saved ancient knowledge and gave us the Renaissance. New York: Penguin Press.

Amjid.M, Hussain.R, Siddiq.S. (2020). Pakistani ESL Learners on the Internet: Explorations into Factors Influencing their Online Language Learning Behaviour. Global Language Review ,V(III),151-162, doi: http://dx.doi.org/10.31703/glr.2020(V-III).16

Asgher, T., \& Hanif, A. (2021). Exploring the Impact of Online Teaching Method on Higher Education during COVID-19 Pandemic: Students' and Teachers' Perspective. Research Journal of Social Sciences and Economics Review, 2(1), 120-134. https://doi.org/10.36902/rjsser-

Ashfaq, M. (April 11, 2021). Funding denial by HEC leaves KP universities in dire straits. DAWN.COM. Retrieved January 16, 2021, from https://www.dawn.com/news/1617518

Borg, W. \& Gall, M. (1989). Educational research: An introduction. New York: Longman.

Bothwell.E. (July 01, 2019 ). Pakistan funding cuts 'disastrous' for Universities. Retrieved January 
16, 2021, from https://www.timeshighereducation.com/news/pakistan-funding-cutsdisastrous-universities

Brown, J. D. (1997). Computers in language testing: present research and some future directions. Language Learning and Technology, 1(1), 44-59. Retrieved from: http://llt.msu.edu/vol1num1/brown/default.html

Bueno S. and Salmeron J. L. (2008). TAM-based success modeling in ERP. Interacting with Computers, 20, 515-523.

Chapelle, C. A. \& Douglas, D. (2006) Assessing language through computer technology. Cambridge: Cambridge University Press

Chapelle, C., \& Douglas, D. (2006). The impact of CALT. In Assessing Language through Computer Technology. Cambridge: Cambridge University Press. doi:10.1017/CBO9780511733116.007

Chapelle, C. A. (2010). Technology in language testing [video]. Retrieved April 26, 2019 from http://languagetesting.info/video/main.html

Dandonoli, P. (1989). Modern Technology in Foreign Language Education: Application and Projects. The ACTFL Computerized Adaptive Test of Foreign Language Reading Proficiency. Lincolnwood, IL: National Textbook.

Gault, R. H. (1907). A history of the questionnaire method of research in psychology. The Pedagogical Seminary, 14 (3): 366-383. doi:10.1080/08919402.1907.10532551

Green, B. F. (1988). Construct validity of computer-based tests. In H. Wainer \& H. I. Braun (Eds.), Test validity (pp. 77-86). Lawrence Erlbaum Associates, Inc.

Heide, F. P \& Gilliland, J. H. (1999). The House of Wisdom. New York: DK Ink.

Indrawati, E. D. (2008). Call and CALT in program for TOEFL IBT Preparation. Retrieved January 13, 2022, from https://efidrew.wordpress.com/2008/07/05/assignment-1-or-mid-semesterassignment/

Kurniawan, H. S. \& Zaphiris, P. (2001). Reading Online or on Paper: Which is Faster? Retrieved from: https://www.researchgate.net/publication/2556185

Larson, J. W., \& Madsen, H. S. (2013). Computerized adaptive language testing: Moving beyond computer-assisted testing. Calico Journal, 2(3), 32-37.

Larson, J. W. (1989). S-CAPE: A Spanish computerized adaptive placement exam. Modern technology in foreign language education: Applications and projects, 277-289.

Levy, M. (1997). CALL in context I: A historical perspective. In M. Levy. Computer Assisted Language Learning: Context and Conceptualization (pp. 13-46). Oxford University Press: New York, NY.

Levy, M. (2009). Technologies in use for second language learning. The Modern Language Journal, 93, 769-782.

Madsen, H. S. (1986). Evaluating a Computer Adaptive ESL Placement Test. CALICO Journal. 4, 41-50.

Madsen, H. S. (1991). Computer-adaptive testing of listening and reading comprehension: The Brigham Young approach. In P Dunkel (ed.), Computer-assisted language learning and testing: Research issues and practice (pp. 237-57). New York: Newbury House.

Mukandutiye, D., Sevilla, J., and Makhanu, E. (2014). Adoption of e-assessment in Strathmore University, IST-Africa Conference Proceedings, 2014, pp. 1-7.

Milliner, B., \& Barr, B. (2017). Computer-assisted language tests for the English classroom: Blackboard $®$ tests and Google Forms (Doctoral dissertation).

Mohsin, B \& Hameed, M.A. (July 15, 2013). Nawab Sadiq Muhammad Khan V, a great reformer and Mohsin-e-Pakistan. Retrieved April 13, 2021, from https://nation.com.pk/25-May2013/nawab-s-national-services-commendable

Neu, J., \& Scarcella, R. (1991). Computer-assisted language learning and testing: Research issues and practice. New York: Newbury House.

Nikou S. and Economides A. A. (2013). Student achievement in paper, computer/web and mobile based assessment, Brain-Computer Interfaces, 4(10) p. 107. Retrieved from:

http://www.academicjournals.org/sre 
Noijons, J. (2013). Testing Computer Assisted Language Testing: Towards a Checklist for CALT. CALICO Journal, 12(1). Retrieved $11 \quad$ February, 2019, from: http://journals.equinoxpub.com/CALICO/article/view/23424/19429

O’Maley, J. M. \& Chamot, A. U. (1990). Learning strategies in second language acquisition. Cambridge: Cambridge University Press.

Pathan, M. (2012). Computer Assisted Language Testing (CALT): Advantages, Implications and Limitations. researchvistas.com. 1. 30-45. Retrieved from, https://www.researchgate.net/publication/260120108

Shamim.F. \&Kuchah.K.(2016). In Hall.G.(Ed), Teaching large classes in difficult circumstances.The Routledge handbook of English language teaching. New york: Routledge

Suvorov, R. \& Hegelheimer, H. (2013). Computer Assisted Language Testing. Approaches and Development: Assessment Approaches, 2(5). 1-20. Retrieved from, https://doi.org/10.1002/9781118411360.wbcla083

Sulaiman, Z. \& Khan, M. (2019). Computer Assisted Language Testing (CALT): Issues and Challenges. 1-11. Retrieved 22 March, 2019, from https://www.researchgate.net/publication/331311015

Sulistyowati, T. (2012). Making large classes smaller: The challenge of teaching English to young learners in Indonesia. In Proceeding the 2nd National Conference on Teaching English for Young Learners in Indonesia (TEYLIN): TEYLIN: from policy to classroom (pp. 162-170). English Education Department, Teacher Training and Education Faculty, Muria Kudus Unversity.

Turner, J. (1993). Using likert scales in L2 research. TESOL Quarterly. 27 (4), 736739

Thomas, L. (2020). An introduction to simple random sampling. Retrieved March 08, 2021, from https://www.scribbr.com/methodology/simple-random-sampling/

Warschauer, M. (1996). Computer assisted language learning: An Introduction. In Fotos S. (ed.), Multimedia language teaching (pp.3-20), Tokyo: Logos International. Retrieved from http://www.ict4lt.org/en/warschauer.htm

Warschauer, M. (1997). Computer-mediated collaborative learning: Theory and practice. The Modern Language Journal, 81(4), 470-481.

West.M. (1966).Teaching English in difficult circumstances. London: Longman 